\title{
ORAL CONSUMPTION OF CAFFEINATED ENERGY DRINKS AFFECTS THE MORPHOFUNCTIONAL STATE OF STRESS- ASSOCIATED ENDOCRINE GLANDS
}

\author{
Tkachenko M. O., Gubina-Vakylyuk G. I., Gorbach T. V., Denysenko S. A., Tkachenko A. S., \\ Onishchenko A. I., Zhurba E. P. \\ Kharkiv National Medical University, Kharkiv, Ukraine
}

The aim of the research was to study the features of the morphofunctional state of the pineal gland, neurohypophysis and adrenal medulla, as well as the content of serotonin and catecholamine in the blood serum of rats against the background of energy drink administration during two weeks. In animals that consumed energy drinks during two weeks at a dose of $6 \mathrm{ml}$ per $\mathrm{kg}$ of body weight, serum serotonin and catecholamine levels were determined. Histological, including morphometric, studies of the epiphysis, posterior pituitary and adrenal medulla were performed. Against the background of energy drink administration, an increase in the content of blood serum serotonin, norepinephrine and epinephrine was detected. The morphofunctional state of the endocrine glands investigated in the present study is strongly stimulated. Indirect signs of apoptosis of parenchymal cells in the pineal gland, neurohypophysis and adrenal medulla were established. The studied stress-associated endocrine glands in animals against the background of the two-week intake of energy drinks have signs of a sharp stimulation of hormone production (serotonin, norepinephrine, epinephrine, and vasopressin).

KEY WORDS: energy drinks, neurohypophysis, pineal gland, adrenal medulla, serotonin, catecholamine

\section{ВПЛИВ ПЕРОРАЛЬНОГО ВЖИВАННЯ ЕНЕРГЕТИЧНИХ НАПОЇВ НА МОРФОФУНКЦІОНАЛЬНИЙ СТАН СТРЕС-ОРГАНІЗУЮЧИХ ЕНДОКРИННИХ ЗАЛОЗ}

Ткаченко М. О., Губіна-Вакулик Г. І., Горбач Т. В., Денисенко С. А., Ткаченко А. С., Оніщценко А. І., Журба $С$. П.

Харківський національний медичний університет, м. Харків, Україна

Метою роботи було вивчення особливостей морфофункціонального стану шишкоподібної залози, нейрогіпофізу і мозкової речовини надниркових залоз, а також вміст серотоніну і катехоламінів у сироватці крові щурів на тлі двотижневого вживання енергетичних напоїв. У тварин, які вживали енергетичний напій протягом двох тижнів у дозі 6 мл на кг ваги тіла, визначали вміст серотоніну і катехоламінів у сироватці крові. Проводили гістологічне, в тому числі морфометричне, дослідження епіфіза мозку, нейрогіпофізу і мозкової речовини надниркових залоз. На тлі прийому енерготоніків виявлено підвищення вмісту серотоніну, норадреналіну i адреналіну у сироватці крові. Морфофункціональний стан вивчених ендокринних залоз різко стимульований. Встановлено непрямі ознаки апоптозу паренхіматозних клітин в епіфізі мозку, нейрогіпофізі й мозковій речовині надниркових залоз. Вивчені стрес-асоційовані ендокринні залози у тварин на тлі двотижневого вживання енергетичних напоїв мають ознаки різкої стимуляції гормонопродукції (серотонін, норадреналін, адреналін, вазопресин).

КЛЮЧОВІ СЛОВА: енергетичні напої, нейрогіпофіз, епіфіз, мозкова речовина наднирників, серотонін, катехоламіни

\section{ВЛИЯНИЕ ПЕРОРАЛЬНОГО УПОТРЕБЛЕНИЯ ЭНЕРГЕТИЧЕСКИХ НАПИТКОВ НА МОРФОФУНКЦИОНАЛЬНОЕ СОСТОЯНИЕ СТРЕСС-ОРГАНИЗИРУЮЩИХ ЭНДОКРИННЫХ ЖЕЛЕЗ}

Ткаченко М. А., Губина-Вакулик Г. И., Горбач Т. В., Денисенко С. А., Ткаченко А. С., Онищенко А. И., Журба Е. П.

Харьковский национальный медицинский университет, г. Харьков, Украина 
Целью работы явилось изучение особенностей морфофункционального состояния шишковидной железы, нейрогипофиза и мозгового вещества надпочечников, а также содержание серотонина и катехоламинов в сыворотке крови крыс на фоне двухнедельного употребления энергетических напитков. У животных, которые употребляли энергетический напиток в течение двух недель в дозировке 6 мл на кг веса, определяли содержание серотонина и катехоламинов в сыворотке крови. Проводили гистологическое, в том числе морфометрическое, исследования эпифиза мозга, нейрогипофиза и мозгового вещества надпочечников. На фоне приема энерготоников обнаружено повышение содержания серотонина, норадреналина и адреналина в сыворотке крови. Морфофункциональное состояние изученных эндокринных желез резко стимулировано. Установлены косвенные признаки апоптоза паренхиматозных клеток в эпифизе мозга, нейрогипофизе и мозговом веществе надпочечников. Изученные стресс-ассоциированные эндокринные железы у животных на фоне двухнедельного употребления энергетических напитков имеют признаки резкой стимуляции гормонопродукции (серотонин, норадреналин, адреналин, вазопрессин).

КЛЮЧЕВЫЕ СЛОВА: энергетические напитки, нейрогипофиз, эпифиз, мозговое вещество надпочечников, серотонин, катехоламины

\section{INTRODUCTION}

Since the appearance of caffeinated energy drinks in Europe in 1987, they have been gaining popularity on the market all over the world [1]. They are used primarily by youth to improve mental and physical performance and endurance. One of the active substances present in such drinks is caffeine. According to Food and Drug Administration, the daily intake of caffeine should be limited to $300 \mathrm{mg}$. However, the content of caffeine per one can or a small bottle of energy drinks may reach $550 \mathrm{mg}$ [2]. Apart from caffeine, caffeinated beverages contain other methylxanthines, glucuronolactone, guarana, group B vitamins, taurine, ginseng, etc. In addition, caffeinated energy drinks have a lot of sucrose [1]. It has been reported that the intake of caffeine-containing energy drinks has been associated with healthrelated problems among their consumers. In particular, it has been demonstrated that the consumption of caffeinated energy drinks and their ingredients affects mood and the state of the nervous system, contributes to the development of cardiovascular disorders, causes changes in the gastrointestinal tract and leads to significant metabolic effects [1-4]. Despite numerous reports about negative effects of caffeinated energy drinks on the metabolism, the cells of such beverages are growing and the energy drink market size reaches over forty billion dollars.

Taking into account the fact that caffeinecontaining beverages affect mood, sleeping and their consumption may result in the development of neurological and psychological effects [2], it is of huge importance to find out how their intake affects the state of stressassociated endocrine glands [5].

\section{OBJECTIVE}

The aim of the research was to study the features of the morphofunctional state of the pineal gland, neurohypophysis and adrenal medulla, as well as the content of serotonin and catecholamine in the blood serum of rats against the background of energy drink administration during two weeks.

\section{MATERIALS AND METHODS}

According to the experiment, twenty WAG adult rats were randomly divided into two groups: experimental $(\mathrm{n}=10)$ and control $(n=10)$. Rats from the experimental group were orally administered caffeine-containing energy drink of the famous brand once per day at a dose of $6 \mathrm{ml}$ per $1 \mathrm{~kg}$ of weight during two weeks. The control group consisted of healthy intact animals.

The European Convection for the Protection of Vertebrate Animals used for Experimental and other Scientific Purposes and Directive 2010/63/EU on the protection of animals used for scientific purposes adopted on September 22, 2010 were strictly followed when carrying out our research. The research design was approved by the Committee of Bioethics (Kharkiv National Medical University).

Animals from both groups were killed by decapitation. The pineal, pituitary and adrenal glands were isolated and fixed in $10 \%$ neutral formalin and embedded in paraffin. Microsections were stained using hematoxylin-eosin and Einarsson gallocyanin chrome alum. In addition to the general description of histological features, a morphometric study was 
performed to determine the area of the nuclei (karyometry) of neuroendocrinocytes in adrenal medulla, pinealocytes, and pituitocytes. The amount of pinealocytes in a limited area of the microslide $\left(S=500 \mu \mathrm{m}^{2}\right)$ was calculated.

Immediately after decapitation, blood was collected in order to obtain serum. The content of catecholamine and serotonin in blood serum was determined using the spectrofluorometric method [6].

«GraphPad Prism 5» was used to statistically process the obtained data. To evaluate the quantitative differences between experi-mental and control groups, the nonparametric MannWhitney $U$ test was chosen. The results were statistically significant at $\mathrm{p}<0.05$.

\section{RESULTS AND DISCUSSIONS}

The tissue of the pineal gland in control animals looks compact with insignificant small voids. Thus, its structure can be considered cellular with signs of the formation of the lobular structure. It is worth noting that many pinealocytes have a large light (euchromic) nucleus with a clearly visible nucleolus. In the pinealogy, such pinealocytes are considered to be peptide-producing. Pinealocytes with darker and angular nuclei are believed to produce indolamines: serotonin and melatonin. It is interesting to note that peptide-producing pinealocytes have eosinophilic cytosol, whereas cytosol in indolamine-generating cells looks vacuolated. Obviously, if pinealocytes simultaneously produce both polypeptides and indolamines, their cytosol seems to be granular or foamy. Such pinealocytes prevail in animals from the control group. Some small-sized «empty» areas can be found in the pineal tissue. They are formed as a result of apoptotic cell death of 1-2-3 pinealocytes (Fig. 1).

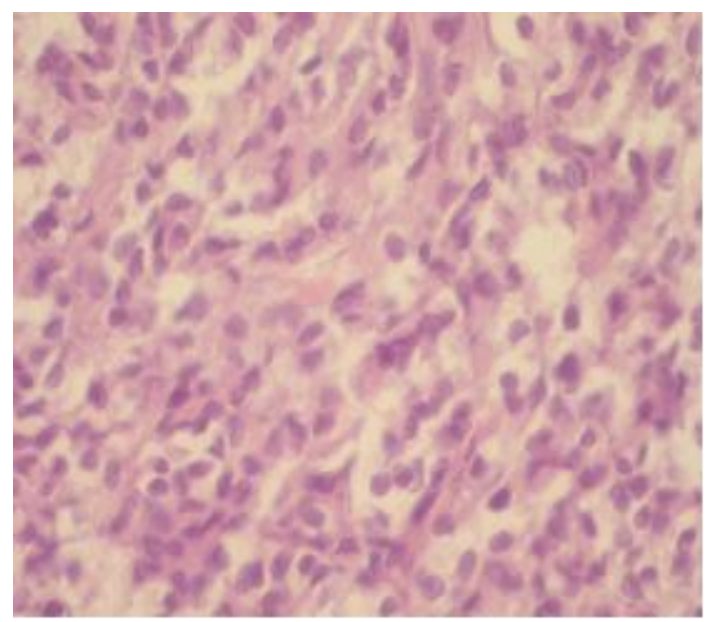

Fig. 1. Pineal tissue of an animal from the control group is compact and cellular. The huge number of pinealocytes with granular cytosol is observed. Hemotoxylin and eosin staining, $x 400$.

In the experimental group, the histological structure of the pineal gland is characterized by the noticeable shift towards the lobular structure. Larger «empty» foci are observed. At their edges isolated pinealocytes are located. Such changes indicate a massive (several pinelaocytes at once) death of pinealocytes by apoptosis. Detailed analysis of the cytological features of pinealocytes allows us to presume that pinealocytes with morphofunctional features of indolamine-producing cells prevail in the experimental group (Fig. 2).

The morphometric study revealed a significant reduction in the amount of pinaleocytes per a fixed area of microslides $\left(\mathrm{S}=500 \mu \mathrm{m}^{2}\right)$ in the experimental group compared to the control group: $5.1 \pm 0.3$ and $7.7 \pm 0.4(\mathrm{p}<0.001)$, respectively. In addition, karyometry showed that nuclei of pinealocytes in the epiphysis in animals from the experimental group are significantly larger than in the control group: $19.23 \pm 0.36 \mu \mathrm{m}^{2}$ and $14.35 \pm 0.34 \mu \mathrm{m}^{2}(\mathrm{p}<0.001)$, respectively. This indicates that pinealocytes have functioned strenuously producing more indolamines.

Compared to the control group, there is an abundant capillary network in the neurohypophysis of animals from the experimental group (Fig. 3, 4). It is well visualized on microslides stained by Mallory. There are clusters of Herring bodies that adsorb alcian blue well along the capillaries, surrounding them (Fig. 4). 


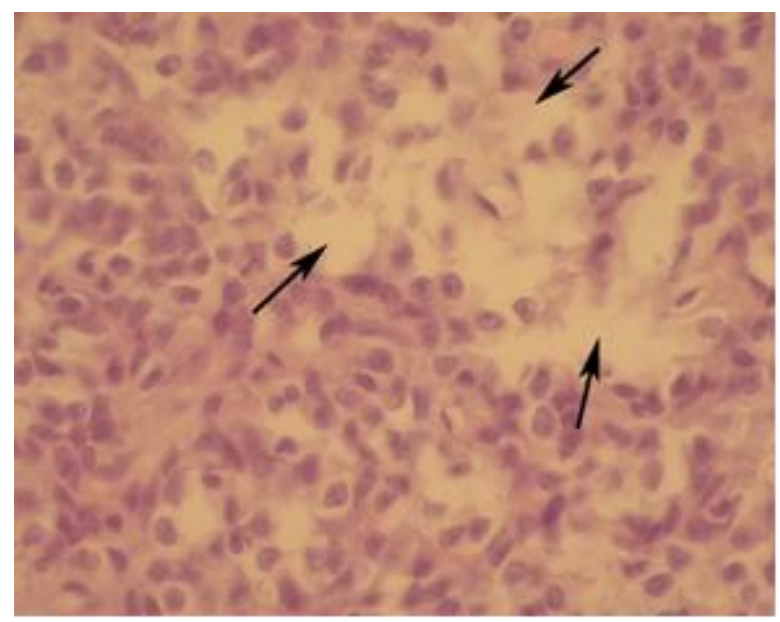

Fig. 2. Pineal tissue of an animal from the experimental group. Empty areas (marked with arrows) with separate pinealocytes are observed. Such changes are probably the result of pinealocyte apoptosis.

The total number of pinealocytes is reduced. Hematoxylin and eosin staining, $\mathbf{x 4 0 0}$.

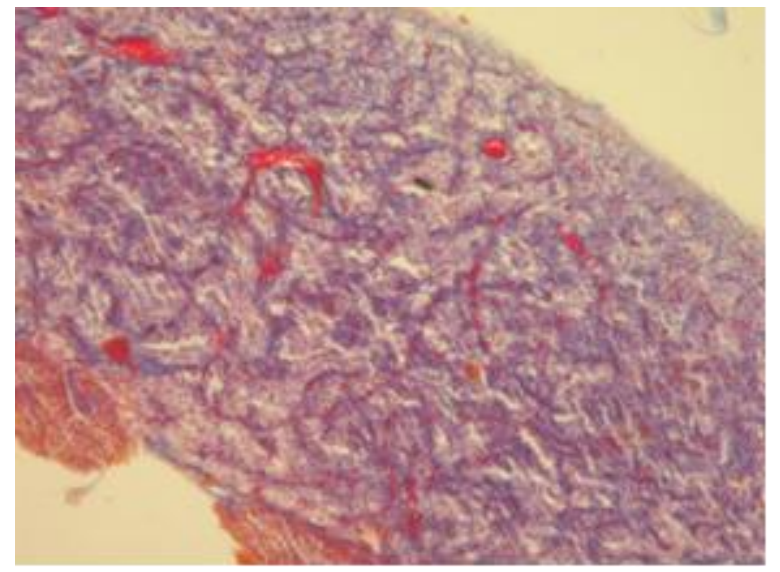

Fig. 3. Posterior pituitary of an animal from the control group. The capillary network is moderate. Along the vessels there are alcian blue-positive formations with spherical Herring bodies. Mallory's staining, x100.

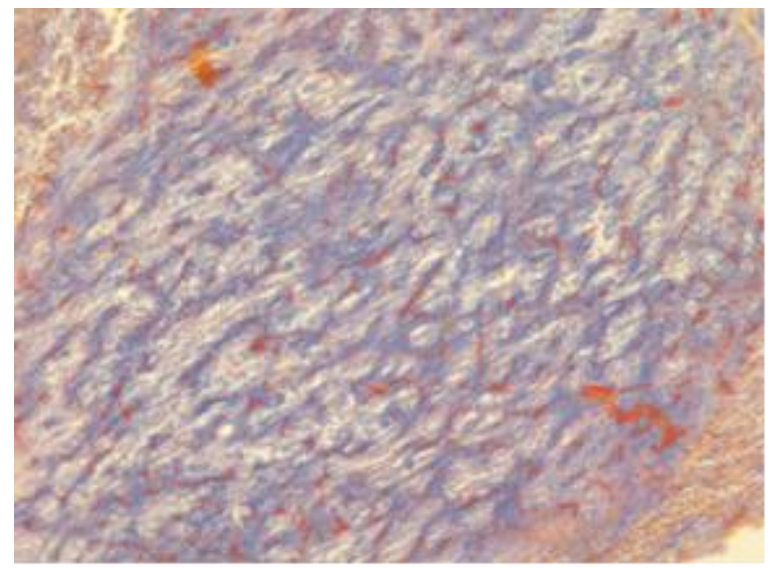

Fig. 4. Posterior pituitary of an animal from the experimental group is characterized by the more pronounced capillary network, higher volume of Herring bodies with the decreased optical density of the substrate. Mallory's staining, x100. 
The accumulation of vasopressin is much more noticeable in the experimental group in comparison with the control group. Pituicytes, which are elements of macroglia and perform trophic and supporting functions, are hyperplastic. Their size is increased: $22.60 \pm$ $0.04 \mu \mathrm{m}^{2}$ in the control group against $23.91 \pm$ $0.05 \mu \mathrm{m}^{2}$ in the experimental group $(\mathrm{p}<0.001)$. The presence of microglia is noticeable, which can be explained by more active apoptotic processes and the need to utilize apoptotic bodies in the neurohypophysis in the experimental group.

Thus, microscopic signs of an increase in the morphofunctional activity of the posterior pituitary gland in animals receiving caffeinated energy drinks at a dose of $6 \mathrm{ml}$ per $1 \mathrm{~kg}$ of body weight were found. Such conclusion is confirmed by a more developed capillary network, the increased accumulation of the substrate in the enlarged Herring bodies, as well as by hyperplasia and hypertrophy of the pituitocytes.

The study of adrenal medulla in animals from the experimental group showed that the cells had a more eosinophilic cytosol with some visible vacuoles. Along with small, dark nuclei there are areas filled with large, light nuclei that sometimes have two nucleoli, which points to polyploidy. A considerable increase in the size of the neuroendocrinocyte nuclei in the experimental group was found. It was $13.6 \pm$ $0.4 \mu \mathrm{m}^{2}$ in the control group and reached $15.3 \pm$ $0.5 \mu \mathrm{m}^{2}$ in the experimental one $(\mathrm{p}<0.01)$, which might indicate an increased synthesis and secretion of catecholamine. Some small cellular debris, probably apoptotic bodies, can be seen occasionally. They indicate the increased load and cell death rate, which is confirmed by the increased morphofunctional load of adrenal neuroendocrinocytes.

Such significant increase in the levels of stress-related hormones and serotonin against the background of the increased morphofunctional activity of pinealocytes (overproduction of indolamines), adrenal and posterior pituitary neuroendocrinocytes leads to the exertion of all regulatory systems, behavioral responses due to compensatory abilities of the body, and creates a high risk of pathological processes. Signs of apoptosis in the pineal gland («empty» areas in the pineal tissue), adrenal medulla (apoptotic bodies) and posterior pituitary gland (tissue is rich in macroglia) indicate the development of atrophization.

Table 1

The content of serotonin and catecholamine in blood serum of animals against the background of caffeinated energy drink administration (Me [25\%; $75 \%]$ )

\begin{tabular}{|c|c|c|c|}
\hline Groups & $\begin{array}{c}\text { Serotonin, } \\
\mathrm{nmol} / 1\end{array}$ & $\begin{array}{c}\text { Norepinephrine, } \\
\mathrm{nmol} / 1\end{array}$ & $\begin{array}{c}\text { Epinephrine, } \\
\mathrm{nmol} / \mathrm{l}\end{array}$ \\
\hline $\begin{array}{c}\text { Control group } \\
(\mathrm{n}=10)\end{array}$ & $203,9[197,1 ; 209,7]$ & $\begin{array}{c}12,44 \\
{[12,06 ; 12,84]}\end{array}$ & $0,86[0,82 ; 0,88]$ \\
\hline $\begin{array}{c}\text { Experimental group } \\
(\mathrm{n}=10)\end{array}$ & $\begin{array}{c}596,2[578,7 ; 612,7] \\
\mathrm{p}<0,0001\end{array}$ & $\begin{array}{c}24,34[22,76 ; 25,10 \\
\mathrm{p}<0,0001\end{array}$ & $\begin{array}{c}2,62[2,30 ; 2,94] \\
\mathrm{p}<0,001\end{array}$ \\
\hline
\end{tabular}

Notes: $1 . n$ is the number of animals in the group; 2. $p$ is a significance compared to the control group

\section{CONCLUSIONS}

1. Oral consumption of energy drinks during two weeks by experimental animals led to morphological changes in the pineal gland (prevalence of indolamine-producing pinealocytes), an increased load on these cells and probably their faster and frequent apoptosis. The number of pinealocytes in the pineal gland decreases and their morphofunctional load increases.

2. Short-term administration (14 days) of caffeinated energy drinks affects the morphofunctional state of posterior pituitary, which can be highly likely interpreted as a result of overproduction of vasopressin.

3. Overproduction of serotonin by pynealocytes and catecholamine by adrenal glands is confirmed by their higher levels in blood serum of animals after the two-week-long intake of energy drinks compared to the control group.

\section{PROSPECTS FOR FUTURE STUDIES}

It is promising to study effects of caffeinated energy drinks on the morphofunctional state of other brain structures and features of neurotransmitter metabolism in them. 


\section{REFERENCES}

1. Energy drink consumption: beneficial and adverse health effects / [A. A. Alumni] // International Journal of Health Sciences. - 2015. - Vol. 9 (4). - P. 468-474.

2. A review of energy drinks and mental health, with a focus on stress, anxiety, and depression / [G. Richards, A. P. Smith] // Journal of Caffeine Research. - 2016. - Vol. 6 (2). - P. 49-63. doi:10.1089/jcr.2015.0033

3. Energy drinks: Potions of illusion / [N. Bedi, P. Dewan, P. Gupta] // Indian pediatrics. - 2014. - Vol. 51 (7). - P. 529-533.

4. Review of published cases of adverse cardiovascular events after ingestion of energy drinks. / [M. Goldfarb, C. Tellier, G. Thanassoulis] // The American journal of cardiology. - 2014. - Vol. 113 (1). - P. 168-172.

5. Meerson FZ, Pshennikova MG. Adaptacija k stressornym situacijam i fizicheskim nagruzkam. M., Medicina, 1988. - 258 p.

6. The neuropharmacology of taurine / [A. Barbeau, N. Inoue, I. Tsukada, R. F. Butterworth] // Life Sci. 1975. - Vol. 17. - P. 669-678. 